\title{
Validity and Reliability of the Indonesia Version of HIV Treatment Adherence Self-Efficacy Scale (HIV-ASES) in Men who have Sex with Men in West Sumatra
}

\author{
Yafi Sabila Rosyad ${ }^{1}$, Hema Malini², Rika Sarfika ${ }^{3}$ \\ ${ }^{1}$ Nursing lecturer, STIKes Yogyakarta, Daerah Istimewa Yogyakarta, ${ }^{2}$ Assoc. Professor, \\ Faculty of Nursing, University of Andalas, ${ }^{3}$ Lecturer, Faculty of Nursing, University of Andalas
}

\begin{abstract}
The aim this study was to translate the HIV Treatment Adherence Self-Efficacy Scale (HIV-ASES) and evaluate its validity and reliability in Men Who Have Sex With Men Seropositive HIV in West Sumatera Indonesia. The original HIV-ASES was translated from English into Indonesian. Validity and reliability testing is done by reliability scale analysis technique. The question item validity is seen from the magnitude of $r$-table value with $r$-count and reliability seen through Cronbach's alpha coefficiency. The results of this study show the HIV_ASES in the context of Indonesian all items of valid and reliable.
\end{abstract}

Keyword: Indonesian, adherence, self-efficacy, HIV/AIDS, MSM, Seropositive HIV.

\section{Introductions}

HIV is a chronic infections disease affecting people wordwide. There were approximately 36,7 milion people living with HIV at themiddle 2017 with 20,9 milion people living with HIV (PLWHIV) currenlyreceving antiretroviral therapy $(\mathrm{ART})^{(1)}$. Indonesia reported the curerenly receiving antireviral therapy (ART) increased from 63,066 in 2015 to 77,780 in 2017 in Indonesia ${ }^{(2)}$.

The use of antriretroviral (ARV) is an attempt to improve the quality of life and reduce the incidence associated morbidity and mortality ${ }^{(3-5)}$. ARVs serve to suppress the proliferation of HIV in the human body to increase CD4 cell counts. The lifetime use ART in people living with HIV make them vulnerable to nonadherence that can lead to resistant virus ${ }^{(6)}$. The use of ART requires a high adherence rate $90-95 \%$ in order to achieve treatment success and may lead to tha onset of drug resistance ${ }^{(7)}$. Therefore, high treatment adherence has important in treatment of HIV/AIDS.

\footnotetext{
Corresponding Author:

Yafi Sabila Rosyad

Nursing lecturer, STIKes Yogyakarta, Daerah Istimewa

Yogyakarta

e-mail: rosyad2yafi@mail.com
}

High level of adherence to antiretroviral therapy (ART) was influenced by internal motivation factor of self-efficacy about ARV. Self-efficacy is the determination of whether a person has ability to complete a certain behavior $^{(8)}$. The self-efficacy of treatment beliefs has an effect on adherence to $\operatorname{ART}^{(9,10)}$. Non-adherence to ART may be affected by low level of education ${ }^{(9)}$. The meaning there is a good treatment success is directly propotional to the high expextation and inversely proportional to the level of depression.

The HIV Treatment Adherence Self-Efficacy Scale (HIV-ASES) ${ }^{(11)}$, have 12-item measurements using Likert scale with range 0-10 "cannot do at all" to "completely certain can do" with total score 120, where someone have good self-efficacy when have score $50^{(10)}$. The purpose of this study was to perform the validity and reliability in Indonesian version of HIV-ASES of Men Who Have Sex With Men (MSM) seropositive population by comparing the r-tab values with r-count and looking at the crobanch's alpha value.

\section{Method And Material}

The analyses presented in this study are based on a total of $20 \mathrm{HIV}+$ at NGOs SaiyoSakato Bukit Tinggi West Sumatra. Eligible participants the following criteria : be at least 18 years old, have provided written informed consent, and have not side effect HIV treatment. 
Questionnaires were completed by participants themselves. The research protocol was approved by the ethical committee of the Faculty of Medicine, Andalas University in Padang. Random sampling used to recruit participant receiving at the NGOs SaiyoSakato Bukit Tinggi in September 2017. Conducted research to examine self-efficacy about ARV using the English version of HIV-ASES. Researcher translate it into bahasa Indonesia. After a process of evaluation of the results of the translation, the researcher tested the validity and reliability of bahasa Indonesia HIV-ASES version.

Test validity is the extent to which a test accurately measures what it is supposed to measure. Reliability is the degree to which an assessment tool produces stable and consistent result in this case is a questionnaire can be used more than once, at least by the same respondent who will produce consistent data ${ }^{(12-14)}$. Validity test was done by doing the correlation between scores of each i variable with total score. Correlation technique used Pearson Product Moment correlation. The test decision compared the $r$ value of each item statement with $r$ table. The r value of the result was seen in the Corrected ItemTotal Correlation column and the $\mathrm{r}$ table value was seen $\cong$ at the $5 \%$ significance level. If $r$ results $\geq r$ table then the question item is valid and otherwise if $r$ result $<r$ table $\stackrel{0}{\infty}$ then the question is invalid. Invalid question items were $\underline{\varrho}$ omitted. Test reliability was done by comparing Alpha Cronbach's (0.6) with $r$ table. If Alpha Cronbach's $\geq r$ the the instrument is reliable, and otherwise if Alpha Cronbach's $<\mathrm{r}$ table then the instrument is not 品 reliable ${ }^{(12-14)}$.

\section{Results And Discussion}

This study focused on the translations and assessment of the reliability and validity of the HIVASES Indonesian version among Men Who Have Sex With Men Living With HIV, providing strong support for the evaluation of this translated scale and confirming that it can be applied in assessing the adherence selfefficacy of MSM HIV+ in Indonesia. Target interventions for low-scoring items can be implemented to improve medication adherence.

Validity test was done by doing the correlation between scores of each variable with total score. Correlation technique used Pearson Product Moment correlation. The test decision compared the $r$ value of each item statement with $r$ table. The $r$ value of the result was seen in the Corrected Item-Total Correlation column and the $r$ table value was seen at the 5\% significance level. If $r$ results $\geq r$ table then the question item is valid and otherwise if $r$ result $<r$ table then the question is invalid. Invalid question items were omitted. Test reliability was done by comparing Alpha Cronbach's (0.6) with r table. If Alpha Cronbach's $\geq \mathrm{r}$ table then the instrument is reliable, and otherwise if Alpha Cronbach' $s<\mathrm{r}$ table then the instrument is not reliable ${ }^{(12-14)}$. HIV-ASES version in Bahasa Indonesia which amounted to 12 items questions obtained r-count value ranged from 0.729-0.929. With the number of respondents 20 then got the value of r-table 0.468 , due to the value of r-table seen from the number of respondents minus 2 means the value of r-table used is at number 48 .

The first question item has r-count 0.907 which means greater than 0.468 it can be concluded that question number 1 is valid. The second question item has a value of $r$-count 0.929 which means greater than 0.468 it can be concluded that question number 2 is valid. The third question item has a value of $r$-count 0.792 which means greater than 0.468 it can be concluded that question number 3 is valid. The fourth question item has a value of r-count 0.879 which means greater than 0.468 it can be concluded that question number 4 valid. The fifth question item has a value of r-count 0.903 which means greater than 0.468 it can be concluded that question number 5 is valid. The sixth question item has a value of r-count 0.869 which means greater than 0.468 it can be concluded that question number 6 is valid. The seventh question item has a value of $r$-count 0.870 which means greater than 0.468 it can be concluded that question number 7 is valid. Item eighth question has a value of r-count 0.886 which means greater than 0.468 it can be concluded that question number 8 is valid. The ninth question item has a value of $r$-count 0.809 which means greater than 0.468 it can be concluded that question number 9 is valid. The ten Item tenth question has a value of r-count 0.856 which means greater than 0.468 it can be concluded that question number 10 valid. The eleven Item tenth question has a value of $r$-count 0.729 which means greater than 0.468 it can be concluded that question number 11 valid. And the last Item tenth question has a value of r-count 0.842 which means greater than 0.468 it can be concluded that question number 12 valid (table 1). Thus, it can be concluded that the HIV-ASES version in Bahasa Indonesia of all items of question is valid.

From the HIV-ASES get value of cronbach alpha $0,972>$ standard cronbach alpha 0,6 which the 
quetionnaire is reliable. This validity and reliability test were supported by several general researches that perform validity and reliability ${ }^{(11)}$, which is the creator of the questionnaire.

At the first test it was found that the seventh question there was a mistake in writing so that the researchers revised again and redistributed. From the results of the validity and reliability test it can be concluded that all items are valid questions and the HIV-ASES version in Bahasa Indonesia was reliable or feasible to be used in seropositive Men Who Have Love Sex With Men population.

Table 1. Validity and reliabily HIV-ASES Indonesian Versi

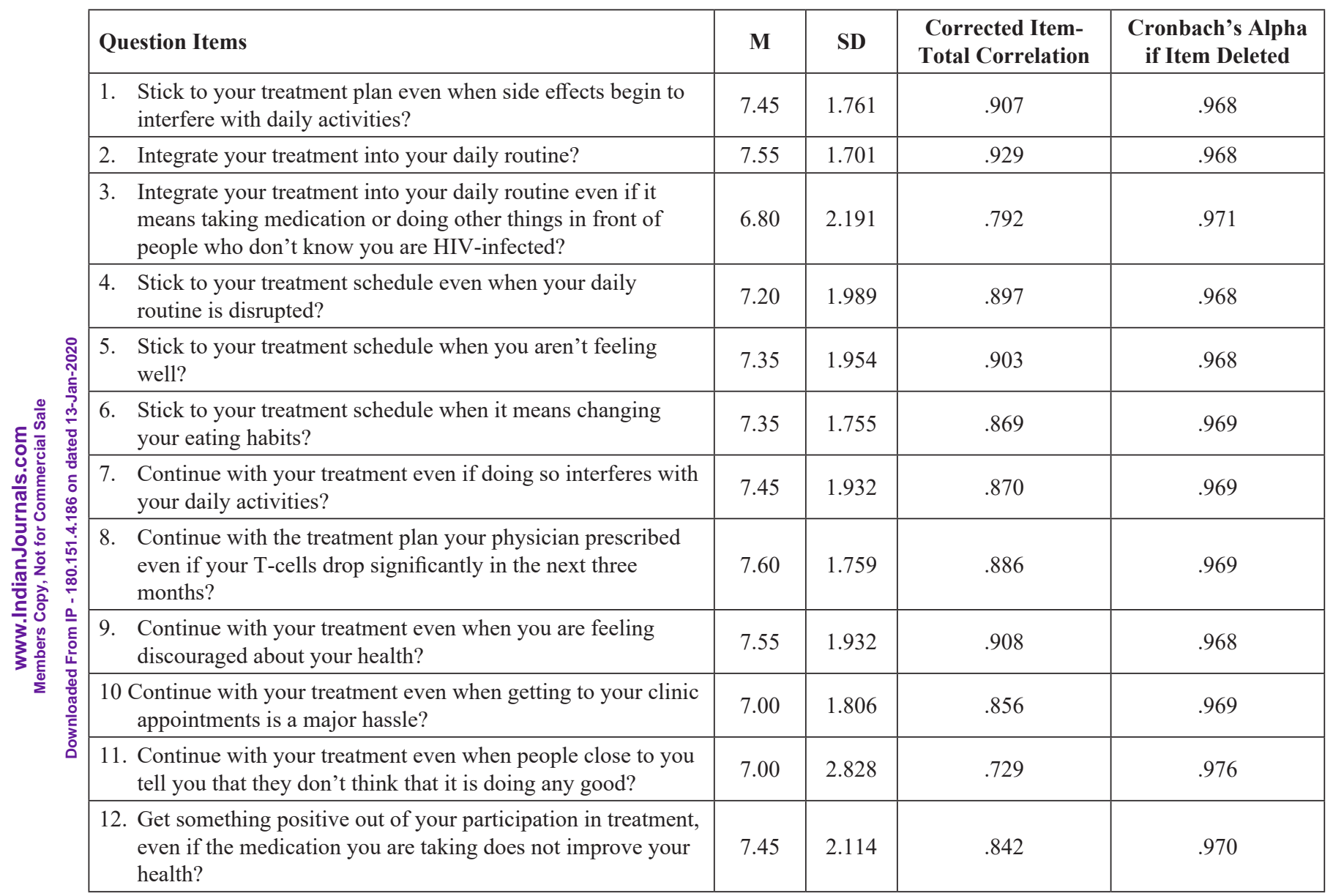

\section{Conclusion}

The HIV-ASES Indonesian Version is a valid and reliable instrument for measuring medication adherence rate of MSM. The Present finding providing HIV-ASES Indonesian Version can use in all community PLWHIV. Prospective studies can be condected to investigate items and MSM with low adherence rate and efficiency of HIV follow-up studies.

Ethical Clearance: This study has passed and granted ethical clearance from the Faculty of Medicine University of Andalas No.346/KEP/FK/ 2018.
Source of Funding: Self-funding

Conflict of Interest: None

\section{Bibliography}

1. WHO. World Health Statistics 2017 Monitoring Health For the SGDs [Internet]. France: WHO Press; 2017. 1-103 p. Available from: http://apps. who.it/iris

2. Kemenkes. Laporan Situasi Perkembangan HIV/ AIDS di Indonesia Januari-Maret 2016. Jakarta; 2016. 
3. Karim QA, Karim SA, Frohlich JA, Grobler AC, Baxter C, Mansoor leila E, et al. Effectiveness and Safety of Tenofovir Gel, an Antiretroviral Microbicide, for the Prevention of HIV Infection in Women. Science (80- ). 2010;329(1168).

4. Wools-Kaloustian K, Kimaiyo S, Diero L, Siika A, Sidle J, Yiannoutsos CT, et al. Viability and effectiveness of large-scale HIV treatment initiatives in sub-Saharan Africa: experience from western Kenya. AIDS. 2006;20(1):41-8.

5. Lowrance D, Ndamage F, Kayirangwa E, Ndagije F, Lo W, Hoover D, et al. Adult clinical and immunologic outcomes of the national antiretroviral treatment programme in Rwanda during 2004 - 2005. J Acquir Immune Defic Syndr. 2009;52(1):49-55.

6. Riyarto S, Hidayat B, Johns B, Probandari A, Mahendradhata Y, Utarini A, et al. The financial burden of HIV care, including antiretroviral therapy, on patients in three sites in Indonesia. Health Policy Plan. 2010;25(4):272-82.
9. Reif S, Proeschold-bell RJ, Legrand S, Uehara A, Asiimwe E, Quinlivan EB. Three types of selfefficacy associated with medication adherence in patients with co-occurring HIV and substance use disorders, but only when mood disorders are present. J Multidiscip Healthc [Internet]. 2013;229 37. Available from: http://dx.doi.org/10.2147/ JMDH.S44204

10. Adefolalu A, Nkosi Z, Olorunju S, Masemola P. Self-efficacy, medication beliefs and adherence to antiretroviral therapy by patients attending a health facility in Pretoria Self-efficacy, medication beliefs and adherence to antiretroviral therapy by patients attending a health facility in Pretoria. South African Fam Pract [Internet]. 2015;6190(November 2016):1-5. Available from: http://dx.doi.org/10.10 80/20786190.2014.975476

11. Johnson MO, Neilands TB, Dilworth S, Morin SF, Remien H, Chesney MA. The Role of Self-Efficacy in HIV Treatment Adherence: Validation of the HIV Treatment Adherence Self-Efficacy Scale (HIV-ASES). NIH Public Access. 2008;30(5):35970.

12. Hastono. Statistik Kesehatan. Jakarta: Rajawali Press; 2010.

13. Creswell J. Research design Pendekatan metode kuantatif, kualitatif, dan campuran. 1st ed. Yogyakarta: Pustaka Pelajar; 2016.

14. Sugiono. Metode Penelitian Kuantitatif, Kualitatif, dan R\&D. 23rd ed. Bandung: Alvabeda; 2016. 